\title{
The 'Atomic' Despatch: Field Marshal Auchinleck, the Fall of the Tobruk Garrison and Post-War Anglo-South African Relations
}

\author{
Dr Andrew Stewart* \\ King's College
}

In January 1948, a despatch written by Field Marshal Sir Claude Auchinleck was published in London. These detailed military operations involving British Commonwealth forces had taken place between November 1941 and August 1942 in the Western Desert of North Africa. Initially submitted to the War Office (WO) five years before, a complex and often bitter political dispute helped ensure that the path of this despatch towards publication would prove a tortuous one. The key reason behind the delay was the South African government's complaints about references to the Tobruk garrison, which, in June 1942, whilst under the command of a South African general, had been forced to surrender to German forces. The drafting of the despatch had begun almost as soon as the final battles had concluded. As a result of his reverses at the hands of General Erwin Rommel and the latter's Afrika Korps, the then General Auchinleck had been dismissed by the British Prime Minister Winston Churchill in August 1942, during the so-called 'Cairo Purge', to be replaced by General Sir Harold Alexander. Alexander declined the offer of the newly created Persia and Iraq command and departed for India, where he later became Commander-in-Chief of the Indian Army, turning his focus to the completion of his account of recent events. ${ }^{1}$

Even in the initial drafts the brief section detailing Tobruk's surrender gave cause for concern to those within Whitehall who read it, and the announcement in November 1943 that there would be no further wartime publication of such reports was perhaps, therefore, fortunate. ${ }^{2}$ It was feared that these despatches could provide valuable information for the enemy hence it was decided to prepare draft versions, which could then be quickly finished when the war drew to a close. ${ }^{3}$ In the event, however, it appears little was actually done before Churchill's announcement, shortly before the end of the war that publication should begin immediately following Germany's defeat. Hurriedly organised meetings, involving the three Service departments and the Cabinet Office, began in July 1945 under the 
chairmanship of Sir Gilbert Laithwaite and six months later an agreement had been reached about how to proceed. ${ }^{4}$

Whilst this was taking place, the political relationship between Britain and South Africa was undergoing considerable changes. During the war years, the close personal friendship between Churchill and Jan Smuts, the South African leader, helped ensure generally excellent relations. With the former's electoral defeat in July 1945 this position rapidly changed. Indeed, with a Labour government now in power Smuts was "appalled at the implications for the future". 5 While his views were still listened to, they now carried nowhere near the same degree of influence as they had enjoyed previously. The new government in London also appeared to be uncertain about the British Empire's future role and this created more general uncertainty in the minds of the United Party in South Africa about what might happen. ${ }^{6}$ Finally there were increasing tensions between Smuts and Dr Daniel Malan, the leader of the Nationalist opposition party, who was enjoying considerable success orchestrating the expansion of Afrikaner power. ${ }^{7}$

With some apparent confusion in Whitehall and simmering political tension in South Africa, Auchinleck's draft account of his period commanding British Commonwealth forces in the North African theatre had been sent from the WO to the Dominions Office (DO). ${ }^{8}$ With its central role of managing Anglo-Dominion relations, the DO was required to read all documents relating to wartime operations involving Dominion troops and to comment about the possibility of any controversy developing. ${ }^{9}$ This was a time-consuming process, described by one of those involved as "cumbrous", and the DO was at once uncomfortable with its role. ${ }^{10}$ These draft reports had to be read by members of the department who had little or no military experience and no intimate knowledge of the incidents they covered. Such reviewers, it was felt, could hardly be expected to make a reasoned judgement as to the technical content of long and generally not very interesting historical documents. ${ }^{11}$

Auchinleck's comments should, however, have made for interesting reading, even to disinterested civil servants. On 20 June 1942, the port of Tobruk, garrisoned by a large force of British, South African and Indian troops, was attacked by a strong German-Italian force. ${ }^{12}$ It was deemed critical to both sides. Although not a natural fortress, the Italians had fortified what was the only good harbour between Benghazi and Alexandria and the only good water supply between Derna and Mersa Matruh. Unfortunately, the British Commonwealth forces proved able to resist the assault for less than two days before surrendering. With just 85 of his men dead, Major General Hendrik Klopper, the General Officer commanding the garrison, surrendered "to 
save "bloodshed"'. ${ }^{13}$ Vast amounts of supplies and equipment were seized and nearly 33000 Commonwealth troops marched into captivity, including virtually an entire South African division. ${ }^{14}$ This was the greatest single military disaster ever experienced by the country's armed forces. The draft commentary forwarded from the WO to its Whitehall neighbour noted that, despite this, Auchinleck had been "for the most part ... very restrained" although some of his conclusions were "based on incomplete evidence". ${ }^{15}$ All of the senior commanders present in Tobruk had been captured by Axis forces, as the British General himself noted; he had therefore been unable to speak with any real conviction about what had actually happened during the garrison's last days and hours. To this end, the WO wondered whether such information might now be available in South Africa and the suggestion was made that some attempt should be made to establish more clearly what had transpired. This initiative would later prove critical, as the DO, which had already warned that it lacked the technical competence to comment on the report's military aspects, appears to have conducted only a cursory review before sending the draft on to the authorities in Pretoria with the WO's instructions.

The reply from the Union took two months to appear and when it did, it took the form of five tightly typed pages representing Klopper's memory of events. ${ }^{16}$ Klopper's account began by detailing how Rommel's forces had conducted probing attacks west and south-west of the Tobruk perimeter for some time prior to the final assault. Klopper next noted that he had been told by both General Gott, the commander of XIII Corps, and General Ritchie, the $8^{\text {th }}$ Army commander, that whilst he could expect to be isolated from the remainder of the British defensive line for a while, the intention was that his position would in fact form the pivot around which a counter-attack would be organised. Consequently, he ordered part of his forces to make suitable preparations to support this attack, which he anticipated would come from the east of his position, an area he believed to be held by British troops. It was only on the night of 19/20 June that patrols sent out by the garrison had discovered the area had been evacuated. It was through this gap that Rommel almost immediately launched his attack. Klopper concluded his comments by discussing at some length the efforts that had been made to repel the German forces. There was "chaos", with "concentrations of thousands of unarmed men awaiting the onslaught", presumably a reference to the port's stevedores, leaving Klopper little option other than to capitulate. Clearly he felt Tobruk had been lost because there had been insufficient preparation of the port's defences during the period prior to Rommel's attack along with the promised Allied counter-attack, which never 


\section{1}

materialised and withdrawals to the east of his position, which allowed German forces to attack through the garrison's flanks. In short, Klopper's argument was clearly inclined towards the conclusion that no fault could be attached to Tobruk's defenders or, more specifically, their commander. Culpability instead lay with decisions made by those who had been outside the perimeter.

It was five weeks after the receipt of this fairly emotive self-justification before the WO approached Auchinleck to see if there were any alterations he now wished to make to his despatch. Field Marshal Auchinleck - he had been promoted in May of that year - was also told at this time that the detailed appendices he had included in his draft were felt merely to repeat information already given elsewhere. ${ }^{17}$ The document therefore had to be heavily reduced in length. He turned to Lt. General Tom Corbett, one of his senior officers who had been with him at the time and whom Churchill had also dismissed, for his views. Corbett spent the next few weeks examining the South African account, also passing it to a barrister who was "a trained logistician and a disinterested person", for his objective opinion. ${ }^{18}$ The conclusion reached by both was that there was no reason for Auchinleck to alter his original draft, which had been produced "in good faith and in the knowledge available at the time". Klopper, they believed, could have "very little cause for complaint". Indeed, the only factual discrepancy to be found was a very minor one relating to the number of six-pounder guns that had been available to the port's defenders.

Although he received Corbett's comments in December 1945, the Field Marshal claimed he was pre-occupied with his duties in India and his formal reply to the WO was not sent for another three months. ${ }^{19}$ His obvious anger had barely reduced in the long interim, more so it appeared more about the decision to shorten his original report than the tone of the comments from Pretoria. His response offered a forceful justification of the report's original length, his conclusion being that any attempt "to publish [it] piecemeal is, in my opinion, wrong and unjust to those whose actions are described in it". Auchinleck nonetheless concluded by professing himself as being anxious to avoid "any injustice" and his recommendation was that Klopper's account be included as an additional appendix with the explanation that it had not been possible to refer the draft account to him beforehand due to his having been captured at Tobruk. Auchinleck may well have felt that this insertion would also perhaps serve to aid his wider argument, that additions such as this and his other proposed appendices were needed in order to help provide "a sense of proportion". The WO was content to include the South African's account but could not be 
induced into restoring the removed material. By the end of August 1946, a version of the despatch -with a few minor alterations - was ready. This was acceptable within Whitehall, and Auchinleck, although not entirely pleased, was willing to sign his name. ${ }^{20}$

Three months later this revised document had reached the galley-proof stage when word was received by the DO that there were problems in Pretoria. ${ }^{21}$ Having reflected on what had happened, General Sir Pierre van Ryneveld, Chief of the General Staff (CGS) in the Union and Smuts' right-hand man and protégé, thought the despatch remained incomplete and, very possibly, erroneous. ${ }^{22}$ His advice to the British High Commission was that "it would be unfortunate for an official account based upon inadequate information to be published at the present juncture". Tobruk remained an important issue in South African minds and, whilst Van Ryneveld recognised that Auchinleck's report was "not intended as a substitute for an official history", in its present form he thought "a good deal of public controversy would be started". His hope, therefore, was that a delay in publication might be possible to allow for the completion of the Union's own study of the incident. ${ }^{23}$ The WO seemed prepared to accept this proposal although there was a growing urgency to press forward as quickly as possible with completion of the despatch. Questions had begun to appear in the British press about why there had been such a long delay and these could not be ignored indefinitely. ${ }^{24}$ With the promise of more detailed comments from South Africa by no later than mid-January 1947, the DO decided to take this opportunity to conduct a more detailed internal review of the contents of the despatch. ${ }^{25}$ This was what it should have done at the outset, but it was now hoped that this would help safeguard against the discovery of any other 'unforeseen' grounds for dispute. During this, Auchinleck's use of direct quotations from the Court of Enquiry, held in Cairo in August 1942, was spotted; there was a longstanding rule that contents from such privileged documents should not be divulged but this had, apparently, been overlooked. ${ }^{26}$ As it was feared that Klopper might request that the findings of the Court of Enquiry be made public, the Field Marshal was asked to make five further changes to his account, which would remove these references, and he once more grudgingly agreed. ${ }^{27}$

Eventually, in the first week of February, the promised response from the Union at last arrived and the "somewhat contentious nature" of some of its comments instantly alerted readers in Whitehall that a potentially serious problem was developing. ${ }^{28}$ Klopper's account now ran to fifteen pages and it was obvious that the account drew heavily on documents supplied to Klopper by the Union 
military historians including, most notably and as had been feared might be the case, a copy of the findings of the Court of Enquiry. ${ }^{29}$ As before, Klopper's aim was clearly the defence of the decisions he had made and the general quality of his leadership during the siege but he was now in a position to expand upon his earlier arguments. For example, he could offer further evidence showing that it was only a few days before Rommel's attack that he had actually been told he was expected to hold Tobruk. The South African General had, however, made the same mistake as Auchinleck in quoting extensively from privileged information and equally prescribed signal numbers. As a consequence, the WO was quick to reject Klopper's report, leaving it once again to the DO to contact the Union authorities and to advise them that further amendments would be needed. South Africa House was, accordingly, told that all the sensitive material would need to be removed, and in light of the "strong public demand" that surrounded the despatch, it was hoped this could be done as quickly as possible. ${ }^{30}$

The authorities in Pretoria replied much more quickly to this latest exchange but with a more sinister tone. Whitehall was bluntly informed that the aim had been for Klopper "to draw attention to inaccuracies and inadequate information in General Auchinleck's draft despatch" and, as such, it had been anticipated that Klopper's comments would "be published in their most effective form". ${ }^{31}$ There was also a reminder of the agreement that before anything could be published the South African government would be given the opportunity to examine the revised text. The DO took this to be a bad development while the WO doubted whether Auchinleck would agree to any further amendments. ${ }^{32}$ The latter was also now apparently no longer willing to accede so readily to the Union's demands about a document that was "a result of the best information available at the time" and that had been "complied in good faith". ${ }^{33}$ A compromise was needed and it was proposed, therefore, that Van Ryneveld should be approached again and asked to approve the publication in full of Klopper's original, more concise set of comments. Even thought there was no shortage of evidence by this stage to suggest that this would almost certainly be rejected, the idea was sent. Another unlikely alternative proposed that an entirely new set of remarks be submitted. There was also the suggestion that, following the publication of the despatch, the Union authorities could release their own more detailed account of the role that had been played by the South African forces.

In discussing these various strategies with the DO, the emphasis remained on the despatches being intended as an account written by the commander at the time in 


\section{4}

light of the information then available. ${ }^{34}$ As such, the intention had never been for the author to be allowed to re-write passages incorporating newly received information at some later date. The best outcome remained the Union government allowing the publication of Klopper's first set of comments, which they could then supplement, if they wished, with their own public statement. If another version not using privileged information was produced this would then have to be shown to Auchinleck and be approved by him, causing further delay. It would also then not be possible to re-send Van Ryneveld the finished despatch, but he would be assured that text referring to his troops had not been amended aside from the addition of the footnote suggested by Auchinleck some months before. Passing this information on to the Deputy British High Commissioner in Pretoria, the DO was unambiguous in its own view, "the Union authorities have not understood our attitude towards Brigadier Klopper's amendments and are not clear about the difference between a dated despatch and a final historical record". ${ }^{35}$ The matter had "dragged on far too long" and now needed to be resolved at the earliest opportunity.

The British diplomat's response offered a clear indication of the seriousness he now attached to the matter. To have any hope of a positive outcome along the lines Whitehall wanted, Richard Sedgwick felt it would be best to pass the matter to the British Military Adviser based in the High Commission who might then deal directly with the South African CGS. ${ }^{36}$ So it was that Brigadier W.K.M. Leader met with Van Ryneveld during the last week of April 1947 to discuss the impasse that had arisen. ${ }^{37}$ The South African at first claimed to "know nothing of the case", despite his many previous interventions, but he soon confided that he could not understand why Klopper was being prevented from quoting from protected documents. Two weeks later he expanded upon this, making clear the rationale for the Union's continuing intransigence on the matter. Leader was told that it all stemmed from the wording of the initial instructions originally received in Pretoria along with the draft despatch. ${ }^{38}$ The August 1945 telegram sent by the DO had stated, exactly as the WO had requested it should, that "more evidence may now be available to His Majesty's Government in the Union of South Africa, in the light of which additions or corrections might be made to the General's account". This had been passed to Klopper who consequently had sought to highlight the inaccurate statements he believed the despatch contained while also identifying other areas that could be construed as "misleading". What the Union authorities could not therefore understand was why their British counterparts refused to acknowledge these inaccuracies and instead wished to publish a document that would "perpetuate error". 
Van Ryneveld was adamant that the Union was "anxious to avoid even the appearance of a controversy", in which "neither party would be the gainer", but the proposed amendments to the original despatch needed to be accepted. As things stood, to ignore them would oblige Klopper to respond in a highly publicised manner with "an account which would rebut the statements to which he takes exception" and "with a force which would be unfortunate". In light of the political situation in South Africa, the inevitable controversy would be potentially disastrous for Smuts.

In the first instance, Leader had little background knowledge of what he would quickly come to describe as a "debacle". ${ }^{39}$ He had not seen Auchinleck's despatch, the various suggested revisions by Klopper, or any of the earlier correspondence on the matter. Critically, he was also apparently unaware as regards the WO's 'house rules' about how such documents should be written and the fact that it was the accepted policy that the author should not make revisions. ${ }^{40} \mathrm{He}$ had, however, been lent a draft narrative outlining events surrounding the garrison's surrender that had been prepared by the Union's chief war historian. It was this that seems to have heavily influenced the views he formed and the approach he subsequently adopted. ${ }^{41}$ From the outset he appeared to feel that Van Ryneveld had been "perhaps more conciliatory than might have been expected". ${ }^{42}$ Reading a copy of Leader's initial progress report, Sedgwick was seriously alarmed, particularly at the references it made to potentially adverse publicity, something that could not fail "to have the most unfortunate consequences". ${ }^{43}$ The fear of what might happen to the vulnerable Pretoria government was all too obvious as he reminded London that Tobruk's fate excited "intense feelings not only in the Union Defence Force but among the South Africans generally". Controversy had to be avoided, hence his suggestion that if Van Ryneveld's proposals remained unacceptable it might even be best that "the idea of publication should be dropped". It can reasonably be assumed that Sedgwick shared this view with Leader who once again turned to the WO for a revised assessment of the situation. ${ }^{44}$ The reply Leader received was that there was no reason to see "the controversy as being in any way unfriendly". With this came a new suggestion, Auchinleck's proposed footnote could be amended to say that Klopper "alone knew the full facts" and that Klopper's account, included as an appendix, was that of the "commander on the spot". Leader was also, however, left in no doubt there remained an unwillingness to accept any wider amendments and that the WO could not and would not "insist on a commander changing his opinion". 45 


\section{6}

No further progress was made in June 1944 as Van Ryneveld had parliamentary commitments and Leader was away on two week's leave. ${ }^{46}$ The British officer took another set of briefing notes to read, once again kindly prepared by the chief historian Lieutenant-Colonel John Agar-Hamilton. These outlined the changes that were considered necessary to resolve the matter and, having digested these and having returned to Pretoria on the last day of the month, Leader once again contacted London. ${ }^{47} \mathrm{He}$ had previously believed a compromise was possible but it was now clear to him that the differences between the two sides were so great that it would be unwise at this point to approach the South African CGS. Leader's intention therefore was to hold discussions solely with Agar-Hamilton, who had taken the lead role on the Union's side and with whom Leader appears to have developed a good rapport. From all that the British Military Adviser had read and heard it was obvious that the idea of publishing the despatch as it stood was "deeply repugnant" to the Union authorities and that it would result in "a serious controversy which cannot but be damaging to the relations between the Dominion and the United Kingdom". This was an outcome he was confident that Van Ryneveld was keen to avoid, in fact he believed the CGS to be quietly supportive of the idea that "the least said by [Klopper] the better". To this end, if Auchinleck would agree to delete just a few statements, "some of which are quite definitely erroneous, and some of which are at the same time damaging to the British commanders themselves", the despatch might yet be published without any additional appendix.

Leader clearly hoped that by highlighting how Auchinleck's reputation would be potentially damaged, the WO would support his proposals. As he told them, any account from the Union would be "brutally frank" and would also show "that the Field Marshal had unnecessarily made inaccurate damaging statements". Leader could also now confirm that Smuts himself had personally approved Klopper's second account and that the South African premier would be "very reluctant to agree" to a published despatch that did not incorporate the comments he made. With this warning, Leader concluded his report to London by forwarding for the WO's consideration, in total twenty-one suggested alterations most of which merely entailed the removal of sections of the original text as opposed to any actual rewriting. In a separate letter sent to General Alfred Ward, the Director of Military Operations, the British Officer was much more outspoken. ${ }^{48}$ Auchinleck's "damaging" and "inaccurate" statements should not have been made in light of the information available at the time and, whether there was anything deliberate about them or not, such statements would be perceived in the Union as being insulting. 
People in London dealing with this matter needed to recognise that, in terms of the consequences that could follow, it was a "potentially atomic subject".

For the next two weeks the WO examined the suggested amendments and considered its response carefully. Having compared the amendments to the text of the original despatch, but without first contacting Auchinleck to seek his opinion, Leader was told that they were acceptable. ${ }^{49}$ Despite the repeated previous assertions that no changes would be forced upon him, it was now decided that other authors had previously agreed to similar changes, "for reason of fact or tact", and this case should therefore be no different; Van Ryneveld's brinkmanship had apparently prevailed. The Union authorities were asked to officially forward the amendments through the Commonwealth Relations Office (CRO), the recently re-named DO, so that they might be sent to the Field Marshal. This outcome suited the diplomats in the CRO who had always maintained that Klopper's version of events should not be included and this meant Klopper's account would not be needed. This approach would offer little to "historical truth" but, as was noted by Sir John Stephenson, one of the most senior officials within the department who had been involved throughout, "truth is a dangerous thing in this matter". ${ }^{50}$ A far greater concern within the department was Sedgwick's suggestion that the despatch be suppressed which, should it become common knowledge, was likely to "cause almost as much controversy as its publication even in the most violent form". 51

Auchinleck's approval of the revisions was all that was needed and, by midAugust, with the formal request received from Van Ryneveld, the WO was in a position to approach him. ${ }^{52}$ It was stressed to the Field Marshal that this was necessary to safeguard good relations between the British and South African governments. ${ }^{53}$ Prominent reference was also made to the fact that the Army Council fully supported the proposed changes and Auchinleck was told that the despatch, as it stood, "would be bound to create embarrassment and ill-feeling". If he would therefore agree to the amendments now proposed this potential would be removed along with the insistence of the authorities in Pretoria that a formal appendix by Klopper be attached. The reply sent from India was, not surprisingly, once again terse but it accepted the changes allowing the much-revised despatch to again be readied for publication. ${ }^{54}$ The end now finally seemed near. The despatch was forwarded to Churchill, who it had been agreed would be allowed to see all the completed wartime commanders' reports prior to their public release. ${ }^{55}$ General Henry Pownall, who read all of these documents for the former Prime Minister, could find little on which to comment. He had also been sent Klopper's appendix but 


\section{8}

even he felt that this document threw little light on the real reasons behind Tobruk's loss. ${ }^{56}$ These final actions were completed against a backdrop of renewed media speculation as to the reasons behind the continuing delay in the preparation of the despatch. The Johannesburg Sunday Times reported that the despatch would "include many controversial points". The newspaper account was remarkably accurate in terms of recounting the diplomatic impasse that had taken place, suggesting a source that was well aware of the background to recent events. ${ }^{57}$ Leader, with the WO's full support, nonetheless issued a public denial of the claims. ${ }^{58}$

Within Whitehall it had meanwhile been discovered that neither the Colonial Office nor the India Office had ever been contacted for their comments on the initial draft, an embarrassing oversight that was quickly corrected. ${ }^{59}$ By the last week of November 1947, arrangements finally appeared complete and the revised despatch was sent to the WO's Permanent Under-Secretary, Sir Eric Street, accompanied by a brief explanation of its slow progress. ${ }^{60}$ Even now, with the document sitting on the Secretary of State's desk awaiting his approval for publication, there remained time, however, for the Union to request one last change. Smuts had spotted a sentence that still troubled him, an "apparently innocuous" line stating, "the exact circumstances of the fall of Tobruk are still unknown". ${ }^{61}$ Throughout the protracted process, political considerations had been central. The South African leader feared this lack of clarity might be seized upon by his opponents forcing him to publish a statement that would provide more fulsome details. The implicit suggestion, once again, was that Smuts would have to make public some or all of the findings of the Court of Enquiry. Over three hundred pages of witness statements in two volumes - and only seven copies of which were produced - actually had little to say on the matter. In fact, there was effectively a single conclusion, "the fact that Tobruk fell must undoubtedly be attributed to the eleventh hour reversal of policy leading to the decision to hold the fortress" which had left insufficient time to make suitable defensive preparations. A brief comment was made about the inadequate positioning of divisional headquarters but no specific mention was made of Klopper, as an individual or as garrison commander, nor any specific reference to South African troops. Although largely innocuous in tone, any reference to the enquiry would only serve to stimulate debate, which could potentially cause difficulties for the British authorities. ${ }^{62}$ Wartime calls had been made for similar enquires to be held - most notably about the loss of Singapore - and the fact that these never took place might now be remembered leading to calls for potentially difficult public investigations. 
The requested change, which was relatively minor, was therefore made with minimal delay. ${ }^{63}$

With this done and almost five years after its original submission, Field Marshal Auchinleck's account was finally published in the London Gazette on 15 January $1948 .{ }^{64}$ Having been so keenly anticipated, its release was covered widely in the British media. The Times, the Telegraph and the Manchester Guardian all noted that the despatch did not really explain why the Tobruk garrison had been forced to surrender so quickly but none of them made any unfavourable reference to the Union's role. ${ }^{65}$ The following day, however, the Daily Express tabloid reported that Klopper was on his way to Cape Town to see Smuts where he apparently intended to give him the ultimatum that he "exonerate his reputation or accept his resignation as Commander, Northern Command, South African Army" ${ }^{66}$ Within forty-eight hours, the South African dismissed the story as "ruddy nonsense" in a telephone interview given to the Daily Mail. ${ }^{67}$ This made it patently clear that what had upset Klopper most was Auchinleck's assertion that the garrison commander had been given permission to attempt to withdraw his forces, but had not. Speaking from the Union, Klopper maintained, "he tried for seven hours" to obtain permission for such a move but by the time it was eventually approved, "Rommel has overrun our guns and cut off our transport". The opportunity to extract his troops had, effectively, been denied to him until it was too late.

Such publicly made claims were clearly politically damaging as they suggested British generals had been quite content to sacrifice South African troops. If it could be shown to be true that Klopper had tried and failed to obtain the necessary authorisation, the blame for having had to surrender so many troops would definitely lie not with Klopper but with his superiors. There were certainly signs of some sympathy for Klopper, even amongst elements of the British media. A commentary published in the tabloid The News Chronicle argued that "the passages in the despatches dealing with this unhappy episode... certainly lacks clarity ... If Klopper demands that the full truth should be told it is fair to him that that should be done". ${ }^{68}$ Klopper had concluded his interview with the Daily Mail with the news that he had asked to be allowed to publish his own detailed account of the garrison's final days. With this being reported in the South African media, the High Commission in Pretoria asked London for advice about what to do if an official response was needed. ${ }^{69}$ Before this could be provided, however, the Union government intervened decisively in the form of a statement given by Smuts in the House of Assembly. This reiterated his support for Klopper but also made it clear 
that there would be little further political assistance if he (Klopper) wished to pursue the matter. ${ }^{70}$ The DO hoped this would "be a broad enough hint to General Klopper that nothing further need be said" and it proved to be the case. ${ }^{71}$

In 1952, the first of the South African official histories were finished, part one of which was authored by Agar-Hamilton. Crisis in the Desert looked at events in North Africa between May and July 1942 and, unsurprisingly, devoted well over one hundred pages to Tobruk's surrender. ${ }^{72}$ Many of the sources used were of a "highly confidential nature", including Smuts' personal copy of the Court of Enquiry findings, and Klopper had also contributed lengthy written reports. ${ }^{73}$ The equivalent British volume would not be published for a further eight years and it made only the briefest of mentions about Tobruk. Major-General I.S.O. Playfair, the author, admitted to his South African counterpart that he had relied less "on the official Despatches than on almost any other type of document" as he believed they were "subject to many limitations". ${ }^{74}$ About Klopper, he would say only that Klopper did not have the experience "in the difficult circumstances to make the best use of the forces available". ${ }^{75}$ The passage of time had allowed passions to diminish but it had been a slow process.

In the immediate post-war years and in its haste to see the wartime despatches completed as rapidly as possible, the WO, at least initially, had failed to grasp the politically sensitive nature of Auchinleck's report. In the Union, against the backdrop of a period of intense political uncertainty, this British commander's personal testimony was seen as suggesting his South African subordinate's leadership had been a major factor responsible for the disaster. As a consequence the authorities in Pretoria, notably Van Ryneveld, were prepared to apply considerable brinkmanship to induce Whitehall to make changes using the implicit threat that relations between South Africa and Britain could otherwise be detrimentally affected. ${ }^{76}$ Whitehall's initial reluctance to force any major written changes on the author had been quite correct; such a document was intended as a commander's personal account and not an historical record. When it was finally realised within Whitehall what could be at stake, a hesitant Field Marshal Auchinleck was consequently persuaded to fall in line. That Auchinleck should then have been cajoled into such changes seems to have been most unwarranted.

Auchinleck's comments had covered an inglorious, embarrassing episode in the British Empire's history. The actual decision to surrender was not the cause of the problem. What made the issue so emotive was identified quite correctly by one 


\section{1}

contemporary review of the finally published report. So much controversy was attached to the June 1942 events because

what leaves a nasty taste in the mouth of the average Englishman is that, despite the positive orders ... that Tobruk was to be held 'at all costs', the surrender was made before a large proportion of the garrison had fired a shot. ${ }^{77}$

Klopper's claims that he wanted to withdraw may have had some truth. No document can be found supporting Auchinleck's claim that he had given his permission but at the same time there was little doubt that the South African was hopelessly unsuited for his role. In preparing the Union's official histories, interviews were conducted with all who had been present. Brigadier, later Major General, George Erskine, who had been General Gott's deputy and present throughout Rommel's offensive, had spoken with a number of those captured at Tobruk and they all reported that "by the early afternoon of the 21 June, Klopper was a beaten man with his head in his hands, bewailing that his 'shell' had been broken and his useless staff stood around, ineffective and inactive". ${ }^{78}$ Smuts himself had been a highly capable military commander who had fought many campaigns and it is difficult to believe that he did not recognise Klopper's apparent limitations. That said a published account authored by a British officer and destined for release at a time of such considerable political uncertainty was not an appropriate medium for discussing the more unpleasant aspects of the port's capitulation. With the post-war relationship between the two countries increasingly unpredictable, the warning of one of the British officials involved, that the truth was indeed dangerous where this despatch was concerned, seems to have been a particularly astute one.

\footnotetext{
*Defence Studies Department (at the Joint Services Command and Staff College (JSCSC), Defence Academy of the United Kingdom) King's College London **All sources are taken from the National Archives, London unless otherwise stated. I am grateful to David Steeds for reading a number of early versions of this paper and the many helpful comments provided. I must also thank a number of anonymous reviewers who provided significant observations, which proved of great benefit. The analysis, opinions and conclusions expressed or implied in this article are those of the author and do not necessarily represent the views of the JSCSC, the UK MoD or any other government agency.
} 
1 'Obituaries; Field Marshal Sir Claude Auchinleck', The Times, 25 March 1981; Captain G.S. Kittor to CGS, 13 March 1942, WO201/500

${ }^{2}$ Ibid., Kennedy to CIGS/VCIGS, 17 June 1943

${ }^{3}$ Clerk to Lambert, 7 May 1943, WO32/10160; ibid., Lambert (AUS) to Kennedy (DMO), 7 May 1943

4 'Publication of Despatches', Minutes of First Meeting, Thursday 5 July 1945, CAB21/2169; ibid., Admiralty to Lambert, 30 May 1945; Lambert to Jacob, 7 January 1946

${ }^{5}$ J.C. Smuts, Jan Christian Smuts (London, 1952), p. 486

${ }^{6}$ James Barber and John Barratt, South Africa's Foreign Policy, 1945-88 (Cambridge, 1990), pp. 25-26; D.K. Fieldhouse, 'The Labour Government and the Empire-Commonwealth, 1945-51' in Ritchie Ovendale (ed.), The Foreign Policy of the British Labour Government, 1945-51 (Leicester, 1984), pp. 83-84

${ }^{7}$ Annette Seegers, The Military in the Making of Modern South Africa (London, 1996), pp. 58-59

${ }^{8}$ Lambert to DO, 3 August 1945, WO32/10160; Lambert to DO, 8 August 1945, DO35/1767

${ }^{9}$ Ibid., minute by Dixon, 14 September 1945

${ }^{10}$ Minute by Pugh, 5 February 1946, DO35/1211

${ }^{11}$ Ibid., Holdgate to Lt. Col Ferguson (WO), 30 August 1946

${ }^{12}$ War Office to C-in-C Middle East, 5 August 1942, WO106/2238A; Chester Wilmot, Tobruk 1941 (Australia, 1944), pp. 4-6; Andrew Stewart, “"The Klopper Affair": Anglo-South African Relations and the Surrender of the Tobruk Garrison', Twentieth Century British History (Vol. 17, No. 4; Winter 2006), pp. 516-544

${ }^{13}$ David Dilks (ed.), The Diaries of Sir Alexander Cadogan, 1938-1945 (London, 1971), p. 461

${ }^{14}$ Major-General I.S.O. Playfair, Official History of the Second World War - The Mediterranean and the Middle East: Volume III, Britain's Fortunes Reach Their Lowest Ebb (September 1941-September 1942) (London, 1960), pp. 265-275

${ }^{15}$ Lambert to DO, 3 August 1945, WO32/10160

${ }^{16}$ Telegram from Defence Chief, Pretoria to High Commission, London, 23 October 1945, Auchinleck Papers (John Rylands Library, University of Manchester), No. 1344

${ }^{17}$ Lambert to Auchinleck, 6 December 1945, WO32/10160

${ }^{18}$ Corbett to W.R. Ridgeway (Auchinleck's Private Secretary), 27 December 1945, Auchinleck Papers, No. 1345; ibid., Foucas (?), 'The Fall of Tobruk - General Klopper's comments on General Auchinleck's Despatch', n.d. (presumed, Dec 1945)

${ }^{19}$ Auchinleck to WO, 19 March 1946, WO32/10160

${ }^{20}$ Ibid., Auchinleck to WO, 23 August 1946

${ }^{21}$ Ibid., Snelling (DO) to Ferguson (WO), 23 November 1946

${ }^{22}$ Carel Birkby, Uncle George: The Boer Boyhood, Letters and Battles of Lieutenant-General George Edwin Brink (Johannesburg, 1987), pp. 2, 65; 'The Empire's Military Leaders', The Army Quarterly, (Vol. 42; April/July 1941), pp. 262-263 
23 Agar-Hamilton to Latham, 29 November 1946, CAB106/570

24 'Letter to the Editor', 17 January 1947, Daily Telegraph

25 Scallan (South Africa House, London) to Machtig (DO), 13 January 1947, DO35/2333

${ }^{26}$ Lambert (AUS, WO) to Sugden, 2 December 1946, WO32/10160

${ }^{27}$ Ibid., Auchinleck to Under Secretary of State for War, 20 January 1947

${ }^{28}$ Stephenson (DO) to Lambert, 8 February 1947, DO35/2333

${ }^{29}$ Ibid., 'General Klopper's Despatch on the Fall of Tobruk', n.d.

${ }^{30}$ Ibid., Stephenson to Scallan, 24 February 1947

${ }^{31}$ Ibid., Scallan to Machtig, 12 March 1947

${ }^{32}$ Ibid., Stephenson to Lambert, 22 March 1947; minute by Lambert, 24 March 1947, WO323/10160

${ }^{33}$ Ibid., Colonel Lynch (MO1-Records) to Lambert, 26 March 1947

${ }^{34}$ Lambert to Stephenson, 29 March 1947, DO35/2333

${ }^{35}$ Stephenson to Sedgwick (Deputy British High Commissioner, Pretoria), 9 April 1947, WO32/10160

${ }^{36}$ Sedgwick to Stephenson, 23 April 1947, DO35/2333

${ }^{37}$ Ibid., Leader to WO, 24 April 1947

${ }^{38}$ Ibid., Van Ryneveld to Leader, n.d. (first week of May 1947)

${ }^{39}$ Report No. 3, Leader to WO, April 1947, WO32/10160

${ }^{40}$ Leader to WO, 24 April 1947, DO35/2333

${ }^{41}$ Ibid., Leader to WO, 7 May 1947

${ }^{42}$ Ibid., Leader to Sedgwick, 7 May 1947; ibid., Leader to USS War Office, 7 May 1947

${ }^{43}$ Ibid., Sedgwick to Stephenson, 4 May 1947

${ }^{44}$ Ibid., Leader to WO, 19 May 1947

${ }^{45}$ Ibid., WO to Leader, 27 May 1947

${ }^{46}$ Report No.4, Leader to WO, 16 June 1947, WO32/10160

${ }^{47}$ Leader to Lt-Colonel G.S. Nangle (MO2), 30 June 1947, DO35/2333

${ }^{48}$ Ibid., Leader to General A.D. Ward, 1 July 1947

${ }^{49}$ Ibid., WO to Leader, 17 July 1947

${ }^{50}$ Ibid., Minute by Stephenson, 28 July 1947

${ }^{51}$ Ibid., Hunt to Stephenson, 28 July 1947

52 Ibid., Lambert to Stephenson, 28 July 1947; Van Ryneveld to Leader, 25 July 1947; Ward to Leader, 28 July 1947

53 Ibid., Lambert to Auchinleck, 16 August 1947

${ }^{54}$ Ibid., Lambert to CRO, 31 August 1947; Snelling to Sedgwick, 6 September 1947

55 Speed to Bridges, 29 May 1946, CAB21/2170; Lambert to Sir Norman Brook, 14 October 1947, DO35/2333

${ }^{56}$ Norman Brook to Churchill, 17 October 1947, CAB21/2172; Winston Churchill's Private Secretary to the Private Secretary to Brook, 1 November 1947, (Churchill College, Cambridge) CHUR4/231A

${ }^{57}$ Leader to WO, 21 October 1947, DO35/2333

${ }^{58}$ Ibid., WO to Leader, 22 October 1947; minute by Hunt, 27 October 1947

59 'Office Note' by Captain Weedon, 10 November 1947, WO32/10160 
${ }^{60}$ Ibid., Lambert to Deputy Under Secretary (A), 25 November 1947; DUS(A) to PUS, 1 December 1947

${ }^{61}$ Sir Evelyn Baring to CRO, 15 December 1947, DO35/2333

62 'Operations in the Western Desert, 27 May 1942-2 July 1942', Report of the Court of Enquiry, Volume One, WO106/2234; Volume Two, WO106/2235

${ }^{63}$ Minute by Lambert, 17 December 1947, DO35/2333; minute by Hunt, 17 December 1947

64 'Operations in the Middle East from 1 November 1941 to 15 August 1942', 15 January 1948, Supplement to the London Gazette, No. 38177

${ }^{65}$ The Times, 16 January 1948, WO32/10160; ibid. Daily Telegraph, 16 January 1948; Manchester Guardian, 16 January 1948

${ }^{66}$ Ibid., Daily Express, 17 January 1948

${ }^{67}$ Ibid., Daily Mail, 20 January 1948

${ }^{68}$ The News Chronicle, 20 January 1948, Basil Liddell Hart Papers (Liddell Hart Archives, King's College London) LH15/4/32

69 'General Klopper's Diary Demanded', The Natal Mercury, 22 January 1948, DO35/2333; High Commission to CRO, 20 January 1948, WO32/10160

${ }^{70}$ Ibid., High Commission to CRO, 22 January 1948

${ }^{71}$ Ibid., Captain Hammond to Lambert, 28 January 1948

${ }^{72}$ J.A.I. Agar-Hamilton and L.C.F. Turner, Crisis in the Desert (May-July 1942) (Cape Town, 1952), pp. 111-223

${ }^{73}$ Ibid., pp. 116, 129, 346

${ }^{74}$ Playfair to Agar-Hamilton, 22 September 1952, CAB140/100

${ }^{75}$ Playfair, Official History of the Second World War - Volume III, pp. 265-275

${ }^{76}$ Ritchie Ovendale, 'The South African Policy of the British Labour Government, 1947-51', International Affairs (Winter 1982/83), pp. 41-45

${ }^{77}$ Lt. Colonel A.H. Burne DSO (New Zealand Army), 'Review of the Auchinleck Despatch', The Fighting Forces (April 1948), (Archives New Zealand) WAII, 11, 6

${ }^{78}$ Erskine to Brigadier Latham, 21 October 1949, CAB106/698 